\title{
Fausto João Forin Alonso
}

Em setembro de 1972 comecei a trabalhar na Santa Casa de São Paulo. Lembro-me de meu primeiro e inesquecível contato, ao adentrar seu jardim, com o majestoso ipê amarelo, cartão-postal da instituição, que estava em plena floração de primavera. Bom augúrio para mim, que me propunha a colaborar voluntariamente no atendimento diário aos pacientes da Dermatologia.

Logo nos primeiros dias de trabalho conheci Fausto Forin Alonso, recém-formado pela turma de 1971, que me procurou para manifestar seu desejo de participar do atendimento dermatológico, também de modo voluntário. Contou-me de sua inclinação pela dermatologia, estimulado que fora por seu tio, consagrado especialista de São Paulo, dr. Fernando Alayon.

Desde os primeiros momentos de convívio diário, surgiram entre nós forte identificação e sólido sentimento de amizade. Fausto tinha qualidades que todos apreciávamos imensamente: dedicação ao trabalho, disposição para ser prestativo a quem dele necessitasse, lealdade para com amigos e companheiros de trabalho. Qualidades essas que o elevaram à condição de uma das figuras mais queridas de nossa Santa Casa. Na medida em que seu prestígio cresceu, no âmbito da dermatologia, essas mesmas qualidades foram reconhecidas, tanto na SBD, como nos numerosos contatos internacionais que ele manteve.

Sua trajetória científica, desenvolvida por 30 anos na Santa Casa de São Paulo, foi de constante crescimento profissional, sobretudo no campo da dermatologia na infância. Diariamente, ao terminar o atendimento em nosso Ambulatório de Dermatologia, dirigia-se ao Pavilhão Condessa de São Joaquim, onde está instalado o Departamento de Pediatria, para dar assistência às crianças ali internadas e que apresentavam alguma manifestação cutânea. Recorde-se que a Santa Casa é hospital de referência, para onde são enviados casos raros e de mais difícil manejo, encaminhados pela rede pública de assistência à Saúde. Como resultado desse atendimento diferenciado, a instituição reúne casuísticas que impressionam e que dificilmente são superadas por outros centros, de qualquer parte do mundo, configurando assim uma situação favorável que projetou Fausto nos cenários nacional e internacional.

Acompanhando seus pacientes com grande dedicação e competência - e com olhos de investigador - Fausto Alonso tornou-se referência mundial no campo da dermatologia na infância. Tive a oportunidade de compartilhar vários de seus estudos, sobretudo os que lhe asseguraram a obtenção dos títulos universitários conferidos pela pós-graduação.

Fausto foi aceito pela Escola Paulista de Medicina (hoje Unifesp), em seu curso de pós-graduação. Apresentou duas teses, tendo eu sido o orientador de ambas. A primeira, para obter o título de mestre, sobre a sífilis adquirida na infância. A segunda, para o doutorado, sobre a síndrome de Bloom. Nos anos seguintes preparou-se para o concurso de professor adjunto, da Faculdade de Ciências Médicas da Santa Casa de São Paulo, objetivo que alcançou com brilho. Culminou sua trajetória acadêmica assumindo, como meu sucessor, a condição de professor titular da disciplina de dermatologia e, simultaneamente, a chefia da Clínica de Dermatologia da Santa Casa de São Paulo.

Sua grave enfermidade, iniciada quando se encontrava no apogeu da carreira profissional e universitária, afastou-o precocemente de nosso convívio, privando-nos de seu convívio e de sua amizade.

Que Deus o tenha em sua Paz.

Nelson Guimarães Proença
In September 1972, I began to work at Santa Casa de Sao Paulo. I remember my first and unforgettable visit, on entering the garden I was faced with the majestic Golden Trumpet tree, the postcard of the institution, that was in the middle of its Spring bloom. A good omen for me, as I intended to collaborate voluntarily with the daily attendance of the patients at the Dermatology department.

During the first days of work, I met Fausto Forin Alonso, recently-qualified in the group of 1971, who spoke to me about his desire to participate in the dermatological service, also in a voluntary form. He told me he had an inclination towards Dermatology, encouraged by his uncle, a consecrated specialist from Sao Paulo, Dr. Fernando Alayon.

Since the first moments of daily contact, a strong identification emerged and solid feeling of friendship. Fausto had qualities that we all appreciated enormously: dedication to work, disposition to be helpful to those who needed him, and loyalty to friends and work companions. Qualities that elevated him to becoming one of the most well-loved figures at our Santa Casa. As his prestige grew, in the field of the Dermatology, those same qualities were recognized, both in the SBD and in the numerous international contacts that he maintained.

His scientific trajectory over 30 years in Santa Casa de Sao Paulo, was one of constant professional growth, above all in the field of Pediatric Dermatology. Each day, after finishing his service at our Clinic of Dermatology, he made his way to the Condessa de Sao Joaquim Pavillion, where the Department of Pediatrics is installed, to see the children hospitalized there that presented some cutaneous manifestation. It should be remembered that Santa Casa is a reference hospital, where rare cases that are more difficult to treat are referred by the public health system. As a result of this differentiated service the institution attends patients that are impressive and rarely seen by other centers, in any part of the world, thereby constituting a favorable situation that projected Fausto into the national and international scenarios.

Accompanying his patients with great dedication and competence - and with investigator's eyes - Fausto Alonso became a world reference in the field of Dermatology in Childhood. I had the opportunity to participate in several of his studies, above all in those that assured him his post-graduation University titles.

Fausto was accepted by the Escola Paulista de Medicina (today UNIFESP), for his Post-Graduate Course. He presented two theses, and I acted as his tutor in both. The first, to obtain his master degree on acquired syphilis in childhood. And secondly for his Doctorate, on Bloom's syndrome. In the following years he prepared for the Adjuvant Professor exams, at the University of Medical Sciences, Santa Casa de Sao Paulo, an objective he achieved with brilliancy. His academic career culminated in becoming my successor, as Professor of Dermatology and, simultaneously, the Head of the Dermatology Clinic of Santa Casa de Sao Paulo.

His serious illness, initiated when he was at the highest point of his professional and academic career, took him precociously from our midst, thus depriving us of his company and friendship.

May God rest his soul.

Nelson Guimarães Proença 


\section{As pessoas não morrem. Elas simplesmente se encantam.}

Guimarães Rosa

O dia 31 de dezembro de 1945 se desenhava especial para o jovem Fausto Alonso. Sua família, oriunda de Ponte Viedra, na Galícia, emigrara da Espanha na primeira metade do século XX, fixando-se no Estado de São Paulo. Exercendo a função de fiscal de cereais, residia agora em Marília com sua esposa, Joana, natural de Jaú e grávida do primeiro filho do casal.

Dona Joana optou pelo parto em sua cidade natal, onde se sentia mais segura e confortável com a presença e o carinho dos familiares. E no último dia do ano, uma data de luz, festa, alegrias e esperanças renovadas, Fausto João Forin Alonso, o Faustinho, veio ao mundo. Por um capricho do destino, oficialmente em Jaú, mas Fausto jamais negou a Marília a condição de cidade de seu coração.

Nessa Marília então bucólica e tranqüila, Fausto fincou suas raízes e suas amizades, das quais sempre se orgulhou e que fez questão de perpetuar. A infância como destacado nadador do Yara Clube sob o comando austero e exigente de seu pai e treinador, a turma de adolescentes, conhecida como Grupo do Cativeiro, que se reunia na praça, os primeiros bailes... E Fausto se vê então na São Paulo gigantesca, tão diferente de sua pacata Marília, onde cursa Medicina e se gradua em 1971 pela Faculdade de Ciências Médicas da Santa Casa de São Paulo, outro de seus orgulhos.

Em 1972 dona Joana sofre um acidente fatal na rodovia Castelo Branco e, três anos após, seu esposo falece em Marília. Fausto vê então sua família reduzida a sua irmã, Ilza, e sua sobrinha Larrissa, nascida no mesmo ano do falecimento do avô e a quem Fausto dedicou o maior e o melhor de seus sentimentos paternais, compensando talvez a ausência de uma filha real que não teria em vida. Impelido pelo destino, adota então a dermatologia e seus amigos como sua segunda família.

Pois foi exatamente aqui, no exercício da dermatologia e no cultivo das amizades, que Fausto se mostrou insuperável. Poucos, como ele, defenderam com tanto afinco a dignidade da especialidade. Fausto não poupava críticas à invasão da dermatologia pelos procedimentos movidos por interesses meramente financeiros e falsamente escudados em uma ciência capenga. Dedicava profundo desprezo aos que banalizavam o ato médico e para esses reservava 0 melhor de sua crítica mordaz e ferina, bem fiel a suas raízes ibéricas. A dermatologia, segundo Fausto, exige respeito por parte daqueles que a exercem. E se algumas vezes, especialmente em seus últimos anos de vida, Fausto pode ter exagerado na forma, foi contudo sempre fiel à essência. Nem a doença que lhe tolheu a vida conseguiu roubar-lhe a coerência.

Fausto encantou-se, no mais literal sentido da epígrafe, e com ele levou um naco enorme destas qualidades - tão escassas hoje em dia - que marcam os grandes homens: a amizade fiel, o caráter retilíneo, a bondade infinita e a doçura da alma. A nós, amigos saudosos, só resta dele nos despedirmos bem a sua maneira: juízo, Faustinho!

\section{People don't die. They are simply enchanted.}

\section{Guimaraes Rosa}

December 31, 1945 was a special day for young Fausto Alonso. His family, originally from Ponte Viedra, in Galicia, had emigrated from Spain in the first half of the 20th Century XX and became established in the state of Sao Paulo. Exercising the function of a Cereals Inspector, he now resided in Marilia with his wife Joana, from Jau, who was bearing the couple's first son.

Mrs. Joana opted to give birth in her home town, where she felt more secure and comfortable with the presence and affection of her relatives. And, on the last day of the year, a day of light, happiness and renewed hopes, Fausto Joao Forin Alonso, known as Faustinho, came into the world. Due to a fluke of destiny, officially in Jau, but Fausto never denied Marilia the condition of being his heartfelt city.

In the then bucolic and calm setting of Marilia, Fausto fixed his roots and friendships, of which he was always proud and insisted on cultivating. As a child he was an outstanding competitive swimmer at Yara Clube under his father's austere and demanding command and coaching, the team of adolescents, known as the "Captivity Group" met at the square, for their first dances... And Fausto then came to gigantic Sao Paulo, so different from his quiet Marilia, where he began to study Medicine and graduated in 1971 at the University of Medical Sciences of Santa Casa de Sao Paulo, another reason for pride.

In 1972, Mrs. Joana suffered a fatal accident in the Castelo Branco highway and, three years after, his wife died in Marilia. It was thus that Fausto saw his family reduced to his sister Ilza and his niece Larrissa, both born in the same year as his grandfather's death and to whom Fausto dedicated the greatest and very best of his paternal feelings, compensating perhaps for the absence of a daughter of his own that he was denied in life. Impelled by destiny, he adopted Dermatology and his friends as his second family.

And it was exactly here, practicing dermatology and cultivating friendships, that Fausto proved to be unbeatable. Few, like him, defended with such vigor the dignity of the specialty. Fausto spared no criticism against the invasion of Dermatology by procedures motivated solely by merely financial interests and falsely shielded in a lame science. He cultivated a deep contempt for those that vulgarized medicine and for these he reserved the best of his cutting and cruel criticism, very faithful to his Iberian roots. Dermatology, according to Fausto, demands respect by those that practice it. It is been sometimes said, especially in his last years of life, that Fausto might have exaggerated in this manner, nevertheless he was always faithful to the essence. Not even the disease that took his life could rob him of his coherence.

Fausto was enchanted, in the most literal sense of the epigraph, and with him he took an enormous piece of those qualities - so scarce nowadays - that mark the great men: loyal friendship, upright character, infinite kindness and sweetness of the soul. To us, his nostalgic friends, we can only bade farewell in his particular manner: Take care Faustinho!

Bernardo Gontijo 